\title{
Comparative analysis of trip generation models according to household characteristics for developed, developing and non-developed provinces in Turkey
}

\author{
NURIYE KABAKUŞ* and AHMET TORTUM \\ Departmentof Civil Engineering, Faculty of Engineering, Ataturk University, 25240 Erzurum, Turkey \\ e-mail: nsirin@atauni.edu.tr
}

MS received 26 July 2017; revised 19 February 2019; accepted 21 February 2019; published online 23 April 2019

\begin{abstract}
Trip generation is the first step of transportation planning and trip distribution, stochastic separation, and assignment of traffic are done at the end of the finding of the values. In the scope of this study, the three provinces were selected from developed, developing, and non-developed provinces in Turkey and the field of the study was determined. In the determined provinces, trip generation models were generated according to the household characteristics by making household transportation surveys in the determined provinces. The aim of this study is to determine the trip generation of provinces of different categories according to the household characteristics related to the size and development situation of the provinces and to determine the factors affecting trip generation in these provinces. Besides, it is decided which one of the multiple linear, poisson, and negative binomial regression models is more appropriate for trip generation and Artificial Neural Networks model is compared with the most significant regression model. At the end of the analyses, Artificial Neural Network models have shown better performance among three different data sets. As a result, Artificial Neural Networks was proposed as an alternative method in the trip generation of the provinces.
\end{abstract}

Keywords. Trip generation; multiple linear regression; poisson regression; negative binomial regression; artificial neural network; household characteristics.

\section{Introduction}

People living in a province continuously engage in activities in order to meet their needs in the direction of certain purposes. They want to engage in these activities without any problem faced with transportation systems. However, transportation problems increasingly occur in our country with the increase of owning a vehicle as well as the growth of the population. The present transportation sites started to fail to meet the need as a result of migration from rural areas to provinces. Main Transportation Plans are being prepared in most of the provinces today in order to meet the present transportation demand, contribute to the healthy urbanization pattern of the province by directing the land usage structure of the province, handle and try to solve all of the transportation problems, and determine the strategies to be realized by predicting the possible future transportation modes. With the studies done in the scope of Main Transportation Plans, investments that will ensure the balanced and coordinated operation of the transportation and to maintain safe and effective movement of people and loads in provinces. The aim of this study includes:

*For correspondence
- to gather the information about trip habits on any weekdays of households living at provinces in the study area

- to determine the factors affecting trip generation in the study areas

- to develop a better methodology for trip generation model in developed, developing and non-developed provinces

- to create a trip generation model in developed, developing and non-developed provinces and thus to facilitate the modelling process of the trip demand

- to determine the trip generation of provinces in different categories according to household characteristic depending on the size and development level of provinces.

In trip generation models, the study focused on to predict the number of trips that were produced for each zone by using socio-economical, demographical, and household characteristic data. The survey form that was prepared for this study was started to be applied in the field in February 2015 and the database was generated by completing field study in 2 months in 3 provinces according to the calculated sample size. With the generated database, analyses that were done by using Multiple Linear Regression (MLR), 
Poisson Regression (PR), Negative Binomial Regression (NBR), and Artificial Neural Networks (ANN) were compared. In the models, trip generations according to household characteristics for trips were evaluated. MLR model, which is one of the widely used statistical methods, is a very strong model when the hypotheses are verified. The trip generation of the household consists of positive integers including zero and shows a discrete distribution. For this reason, PR and NBR models, which are named as count data models and widely used in analyses in the last years, were used in the modeling of trip generation. PR model is preferred more in count data models. Whereas PR model serves better in homogeneous conditions, NBR model is more widely used under heterogeneous conditions [1].

Goulias et al have modeled the prediction of homebased and not home-based trips with the traditional approach in trip generation in the study that they have done in 1991 [2]. Rengaraju and Satyakumar have developed MCA (multiple classification analysis) tables for the trip generation in India in the study that they performed in 1994 [3]. These include variables such as house size, vehicle ownership, and house income that are effective in trip generation. MCAs include two variables such as regression analysis and household interviews that are used as an alternative for trip ratios. Later in 1995, they developed a new method by adding parameters for trip quality and trip length besides socio-economical properties such as house size, vehicle ownership, and house income in addition to this study [4]. Anderson and Malave have carried out traditional transportation modeling activities in medium-scale urban societies in the process of four-step planning. These steps include trip generation, trip distribution, mode selection, and assignment of the traffic. They have decided on Huntsville city as study area by preselection and investigating population census information. Data were obtained for 5- and 15-minute periods in peak hours (7:30-8:30) on Tuesday, Wednesday, and Thursday, in which there was no special activity, holiday, or extreme weather conditions by dividing the study field into zones and generating data sets for each zone. Regression analysis was done with these data sets. Besides, number of the houses, the average income of the region, residency percentages according to age, household size of the region, and the distance to central business region were socioeconomic variables that were used in the model. Anderson and Malave presented a step in the process directed towards the development and application of dynamic transportation models for medium-scale societies with the study done [5]. Tillema et al have explained the performance of trip generation and trip distribution models, which constitute the transportation planning steps, with Artificial Neural Networks and compared regression analysis and affinity models analysis that are usually used in these methods with Artificial Neural Network analyses [6]. Badoe and Chen have developed a trip generation model by collecting data with cross-sectional trip surveys.
They have done surveys on 67,000 households in 1986, 22,000 households in 1991, and 26,000 households in 1996 via telephone conversation in Toronto region. They have applied surveys to 115,000 households in total and generated a data set. They have compared the empirical results of 7 models, which were generated with variables such as the number of adults, the number of vehicles, the number of people having a driving license, the number of children, the number of working people, and the number of students [7]. Jang has used count data model in order to compensate the lack of linear regression model, which is used for trip generation, one of the four-step trip demand prediction models [8]. Gamas et al have predicted trip generation in Mexico with province density and spatial effects in their study [9]. Kwigizile and Teng have built a database with variables such as personal trips, land usage, aim zones, demographical socio-economical characters, and geographical position. In this study, they have investigated trip affinity models and trip generation models [10]. Oyedepo and Makinde have used the regression model for determining household trip generation in AdoEkiti, Nigeria. They have defined three trip generation purposes: 1) home-based for work purposes, 2) homebased for other purposes, 3) not home-based. They have used such socio-economic variables as age, family size, income, and car ownership as independent variables in the model [11]. Lim and Srinivasan have compared the analyses of 4 different econometric structures for trip generation by using 2001 and 2009 national household trip surveys. They have divided trips into three groups as HBW (home-based work trips), HBO (home-based other trips), and NHB (not home-based trips) according to their purposes. They have chosen house size, number of working people, vehicle/driver ratio, having children, income, having a house, residential area, regional population, days of the week, and seasons as independent variables. They have generated linear regression, Loglinear Regression, Negative Binomial, and Ordered Probit models as econometric structure [12]. Daniel and Ituen have selected Akwa Ibom state, which is one of the 36 states of Nigeria with 3.5 million population, as study field. They have analyzed the effect of socio-economic variables that affect trip generation by predicting the future trip in the region in their study [13]. Huntsinger et al have evaluated the benefits of cumulative logistic regression model for trip generation prediction in their study [14]. Chang et al have compared the performances of trip generation models by predicting the number of trips from traffic analysis zones. Although there are several approaches, they have suggested regression and category analysis, which is the most widely used one for this step. They have selected Seoul metropolitan region, which is the biggest and capital province of Korea, as study field and they have applied regression, tobit, poisson, ordered logit, category, and multiple classification analyses for work-based trips for this region [15]. 


\section{Materials and methods}

\subsection{Determination of the study field}

Three provinces were determined as study field in Turkey. The first one is Ankara, the capital of Turkey. Ankara has a position close to the center of Turkey and it is the second province of Turkey in terms of its population and the third province in terms of its surface area. Erzurum, which is the second study field, is the biggest province of East Anatolia Region and it is the 27 th province of Turkey in terms of its population and the 4th province in terms of its surface area. Bayburt, the third study field, is one of the smallest provinces of Turkey in terms of population and surface area. Decisions were made according to the development indexes of the provinces while determining the study field (appendix 1). The capital province, Ankara, was selected from the most developed provinces group, Erzurum was selected from developing provinces, and Bayburt was selected from nondeveloped provinces. In the scope of the study, trip generation models were generated for these three provinces and their comparative analyses were done. Household surveys were done in these provinces in the direction of sample sizes calculated according to their populations with the purpose of determining the effects of household characteristics on trip generation. Demographic, household characteristics and trip data were obtained with household surveys. In the light of these three data groups, databases were generated for Ankara, Erzurum, and Bayburt and modeling was done with regression analysis methods and Artificial Neural Networks. In this way, trip generations of provinces with different development levels will be determined and the effects of the household characteristics of these provinces of different development levels on trip generation will be compared.

\subsection{Calculation of the sample size}

The liability, validity and usability of the results obtained in scientific research are related to the quality of the source from which the data were collected. The focus of the research consists of reaching the correct information and deciding correctly in the light of this information. For this reason, reaching the correct information has created the need for generalizing the obtained information. In some researches, the whole data can be reached in small spaces that consist of a restricted number of members. However, in most of the studies, the spaces of the subjects to be investigated are big. It is impossible and meaningless to reach all of the members in these big spaces in terms of time, cost and labor. The research that requires the highest amount of information by spending a certain time, effort and money is the best research. Obtaining less information than required causes problems in reaching the goal such as collecting more information than required causes waste in terms of economy [16].
Table 1. Central District Population of Province [17], Sample Size and number of survey.

\begin{tabular}{lcccc}
\hline Province & Population* & $\begin{array}{c}\text { Size of } \\
\text { calculated } \\
\text { sample }\end{array}$ & $\begin{array}{c}\text { Number of } \\
\text { survey in } \\
\text { analysis }\end{array}$ & $\begin{array}{c}\text { Per } \\
\text { capital } \\
\text { trip }\end{array}$ \\
\hline Ankara & 4.822 .839 & 384.12 & 600 & 1,902 \\
Erzurum & 399.683 & 383.79 & 400 & 1,49 \\
Bayburt & 63.848 & 380.37 & 385 & 1,48 \\
\hline
\end{tabular}

*Central District Population (2014).

The space, which is the subject of the studies, can be of a narrow scale that includes a small number of people such as it can be of a wide scale that includes millions of members. The researcher can determine the space according to the aim of his/her own study. In this study, 3 provinces were selected namely Ankara, Erzurum, and Bayburt according to their development indexes. The sample sizes of these provinces were calculated according to their populations and demographical data, household characteristics, and trip information of 1385 houses and 5832 people were obtained by preparing household transportation survey form with the survey form applied in Ankara, Erzurum, and Bayburt. The sample size, which was calculated for the provinces with the help of Eq. (1), is given in table 1 (the household surveys were made by ASY Consulting Company).

Calculation of the sample size;

If the number of elements in the universe are known;

$$
n=\frac{\mathrm{N} \cdot \mathrm{p} \cdot \mathrm{q} \cdot z^{2} \alpha / 2}{(N-1) \mathrm{d}^{2}+\text { p.q. } z^{2} \alpha / 2}
$$

In formulas;

$\mathrm{N}=$ the number of individuals in the universe

$\mathrm{n}=$ the number of individuals in the sample

$\mathrm{p}=$ the incidence of the events to be examined

$q=$ not the incidence of the events to be examined (1-p)

$\mathrm{z}=$ theoreticial values in $\mathrm{z}$ table at the level of the detected error.

$\mathrm{d}= \pm$ deviation according to the incidence of the event as symbolized.

\subsection{Generation of the data set}

The data set used in the study includes the trip information of 5832 people and the characteristic properties of 1385 houses, which were obtained by applying household transportation survey study in Ankara, Erzurum, and Bayburt. Besides, the data set consists of 13 independent variables and one dependent variable. Six of the independent variables are categorical variables and the others are discrete variables. The total trip of the house was taken as dependent variable in the data set and the independent variables are listed below. 


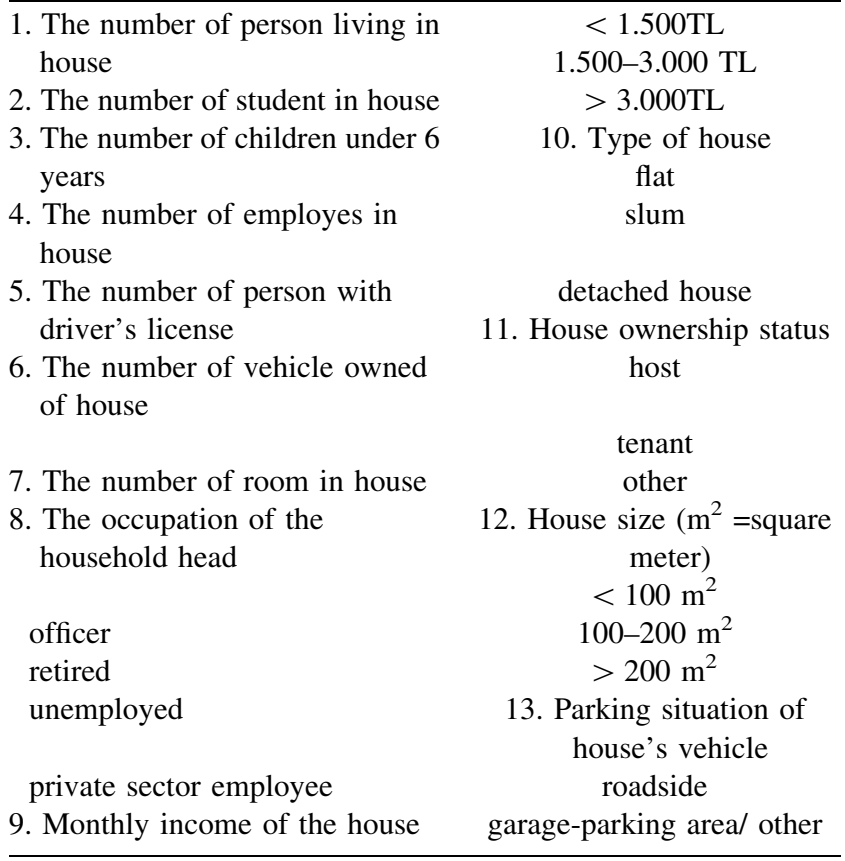

In this study, the models are selected according to dependent variable that total trip of households. This variable is discrete and quantitative. Thus, MLR, PR and NBR models are selected.

\subsection{Multiple linear regression model (MLR)}

There are two types of linear regression such as simple linear regression and multiple linear regression. Simple linear regression analysis is done if the relationship between the dependent variable and one independent variable is investigated and multiple linear regression analysis is done if the relationship between the dependent variable and several independent variables is investigated.

MLR model for trip generation is as follows:.

$$
\begin{aligned}
& \mathrm{Y}=\beta_{0}+\beta_{1} \mathrm{X}_{\mathrm{i} 1}+\beta_{2} \mathrm{X}_{\mathrm{i} 2}+\cdots+\beta_{\mathrm{n}} \mathrm{X}_{\mathrm{in}}+\varepsilon, \\
& \quad \mathrm{i}=1,2,3 \ldots, \mathrm{n}
\end{aligned}
$$

can be written [18].

$\mathrm{Y}=$ the number of trips that each house produces, $\mathrm{i}=$ the number of houses, $\mathrm{n}=$ the number of independent variables, $\beta_{\mathrm{n}}=$ predicted multiplier against $\mathrm{X}_{\mathrm{n}}, \mathrm{X}_{\mathrm{ni}}=\mathrm{n}$ independent variables for $\mathrm{i}$ houses, $\varepsilon=$ Error term.

\subsection{Poisson regression model (PR)}

Poisson regression analysis is a method that is used when the relationship between a discrete numeric dependent variable and one or more independent variables is investigated. Discrete numeric values are always positive and for this reason, poisson average is positive.

$$
\begin{gathered}
\log _{\mathrm{e}}(\mathrm{Y})=\beta_{0}+\beta_{1} \mathrm{X}_{\mathrm{i} 1}+\beta_{2} \mathrm{X}_{\mathrm{i} 2}+\cdots+\beta_{\mathrm{n}} \mathrm{X}_{\mathrm{in}}+\varepsilon \\
\mathrm{Y}=\left(\mathrm{e}^{\beta 0}\right)\left(\mathrm{e}^{\beta 1 X 1}\right)\left(\mathrm{e}^{\beta 2 X 2}\right) \ldots \\
\mu_{i}=\mathrm{E}\left(\mathrm{y}_{\mathrm{i}} \mid \mathrm{x}_{\mathrm{i}}\right)=\mathrm{V}\left(\mathrm{y}_{\mathrm{i}} \mid \mathrm{x}_{\mathrm{i}}\right)
\end{gathered}
$$

As can also be seen in the formulations, PR is the logarithmic transformation of the linear function of predictors. In poisson distribution, the average and the variance are equal, namely, there is an equal distribution. Usually in samples, variables have a variance greater than the average. In this case, we can talk about extreme distribution. In PR model with extreme distribution, the obtained predictions are consistent, but they are not effective [19].

\subsection{Negative binomial model (NBR)}

Negative binomial regression model is a model obtained from the mixture of poisson and gamma distributions. NBR model, which is more widely known as regression model, is based on probability distribution function and it is formulated as follows [20]:

$f(\mathrm{y} ; \mu, \alpha)=\frac{\Gamma(y i+1 / \alpha)}{\Gamma\left(y_{i}+1\right) \Gamma(1 / \alpha)}\left(\frac{1}{1+\alpha \mu_{i}}\right)^{\frac{1}{\alpha}}\left(1-\frac{1}{1+\alpha \mu_{i}}\right)^{y_{i}}$ $y i=0,1,2 \ldots$

$$
\begin{aligned}
& \mu_{i}=\mathrm{E}\left(\mathrm{Y}_{\mathrm{i}}\right) \\
& =\exp \left(\beta_{0}+\beta_{1} \mathrm{X}_{\mathrm{i} 1}+\beta_{2} \mathrm{X}_{\mathrm{i} 2}+\cdots+\beta_{\mathrm{n}} \mathrm{X}_{\mathrm{in}}+\varepsilon\right) \\
& \mathrm{i}=1,2,3, \ldots, \mathrm{n} \\
& \operatorname{Var}\left(\mathrm{Y}_{i}\right)=\mu_{\mathrm{i}}+\alpha \mu_{\mathrm{i}}^{2}
\end{aligned}
$$

In the formula, $\alpha$ is the distribution parameter and if it is not very different from zero, there is equal distribution and it turns into poisson regression model $\left(\mathrm{E}\left(\mathrm{Y}_{\mathrm{i}}\right)=\operatorname{Var}\left(\mathrm{Y}_{\mathrm{i}}\right)=\right.$ $\left.\mu_{i}\right)$. Negative binomial regression is a special version of poisson regression. In negative binomial regression solution, parameter estimations $\left(\beta_{0}+\beta_{1} \ldots\right.$ and $\left.\alpha\right)$ are obtained by using maximum likelihood method with the help of Newton-Raphson algorithm [20].

\subsection{Artificial neural networks (ANNS)}

Artificial Neural Networks are information-processing systems that are developed in order to be able to form new information and discover by learning, making use of the physiology of human brain. Haykin describes ANN as a processor, which is in a trend towards storing the obtained data and presenting this data for usage when required [21]. Besides, Haykin compares ANN to human brain in that it 


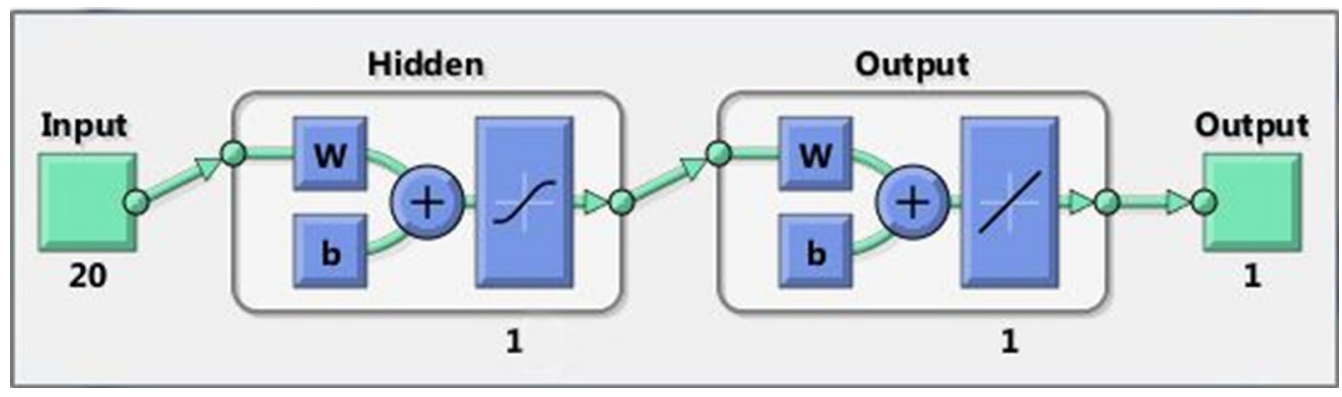

Figure 1. Artificial neural network model structure for trip generation.

obtains information via the network with the process of learning and it stores information with the synaptic connections between the neurons. Artificial Neural Networks is a modeling technique, which is very attractive in the last ten years. It functions by taking the operation system of biological nervous system as an example. Artificial Neural Network (ANN), which is an artificial intelligence technique, is an effective technique used in recognition, classification, prediction and optimization.

The learning property of ANNs, which is one of the most important properties that attracts the attention of the researchers, namely, its property to be able to produce solutions for events that were never seen before by learning the linear or non-linear relationship between the inputs and outputs related to an example from the present examples, is the basis of the ANNs theoretical structure [22].

The structure of Artificial Neuron consists of 5 members [23]. These are; inputs, which include the data set generated from the examples coming from the outer world, weights, which show the importance of the data coming to the artificial cell and their effect in the cell, addition function, which calculates the net input that comes to the cell, activation function, which processes the net input that comes to the cell and determines the net output that it will produce in return to this input, and the output value, which is determined by the activation function.

Analyses were done by using Matlab 14.b software. $\mathrm{R}^{2}$ and RMSE were considered together as performance criteria. The lowest error value and the highest $R^{2}$ value were tried to be reached by trying the data set as $60 \%$ training, 20\% validation, $20 \%$ test for the first time, $70 \%$ training, $15 \%$ validation, and $15 \%$ test for the second time, and $80 \%$ training, $10 \%$ validation, and $10 \%$ test for the third time, and different numbers of neurons, different activation functions, and different learning algorithms. Different web structures to carry out the application were tried as 20-1-1 and 20-2-1 (input layer-latent layer-output layer) and the number of the neurons that will take place in the latent layer in the web architecture was tried between 10 and 30 and the optimum result was tried to be reached.
A web architecture that has only one latent layer was chosen in ANN models. In the latent layer, 30 process (nerve) members were used for Ankara, which has shown the best performance, 24 process members were used for Erzurum, and 21 process elements were used for Bayburt and the ANN architecture for the model was used in figure 1.

Data were normalized before bringing into training. $70 \%$ of the data were used in training, $15 \%$ of them were used in validation, and $15 \%$ of them were used in the test. Levenberg-Marquardt algorithm was used as training algorithm. Log sigmoid function was used as activation function.

Table 2. Multiple Linear Connection: VIF Values.

\begin{tabular}{lccc}
\hline $\begin{array}{l}\text { Province } \\
\text { variables }\end{array}$ & $\begin{array}{c}\text { Ankara } \\
\text { VIF }\end{array}$ & $\begin{array}{c}\text { Erzurum } \\
\text { VIF }\end{array}$ & $\begin{array}{c}\text { Bayburt } \\
\text { VIF }\end{array}$ \\
\hline host & 6,78 & 4,53 & 4,03 \\
tenant & 6,54 & 4,39 & 4,02 \\
vehicle ownership & 3,58 & 2,39 & 2,48 \\
garage-parking area & 3,49 & 2,11 & 1,77 \\
number of person & 3,04 & 2,76 & 3,68 \\
roadside & 2,77 & 2,04 & 1,93 \\
number of student & 2,31 & 2,66 & 2,18 \\
3.000 TL & 2,24 & 2,07 & 1,76 \\
number of employe & 1,76 & 1,89 & 2,4 \\
number of room & 1,71 & 1,43 & 1,71 \\
1500-3000 TL & 1,71 & 1,57 & 1,4 \\
flat & 1,64 & 1,29 & 1,19 \\
slum & 1,63 & 1,16 & 1,12 \\
driver's license ownership & 1,62 & 1,45 & 1,43 \\
200 m & 1,58 & 1,34 & 1,52 \\
number of children & 1,54 & 1,54 & 1,49 \\
retired & 1,35 & 1,58 & 1,23 \\
100-200 m ${ }^{2}$ & 1,26 & 1,57 & 1,51 \\
officer & 1,19 & 1,54 & 1,21 \\
unemployed & 1,1 & 1,46 & 1,11 \\
mean VIF & 2,44 & 2,04 & 1,96 \\
\hline
\end{tabular}


Table 3. Regression Analysis Results of Ankara Province.

\begin{tabular}{|c|c|c|c|c|c|c|c|c|c|}
\hline \multirow{2}{*}{ Variables } & \multicolumn{3}{|c|}{ Multiple Linear Regression } & \multicolumn{3}{|c|}{ Poisson Regression } & \multicolumn{3}{|c|}{ Negative Binomial Regression } \\
\hline & Coefficient & t-Statistic & $\mathrm{P}>\mathrm{z}$ & Coefficient & t-Statistic & $\mathrm{P}>\mathrm{Z}$ & Coefficient & $\mathrm{t}$-Statistic & $\mathrm{P}>\mathrm{Z}$ \\
\hline Constant & 3,143 & 3,12 & 0,002 & 1,288 & 7,29 & 0,000 & 1,403 & 7,63 & 0,000 \\
\hline Number of person & 0,735 & 5,34 & $0,000 *$ & 0,116 & 5,02 & $0,000 *$ & 0,116 & 5,02 & $0,000 *$ \\
\hline Number of student & 0,524 & 3,37 & $0,001 *$ & 0,078 & 3,06 & $0,002 *$ & 0,078 & 3,06 & $0,002 *$ \\
\hline Number of children & $-0,344$ & $-1,58$ & 0,115 & $-0,048$ & $-1,28$ & 0,199 & 0,048 & $-1,28$ & 0,199 \\
\hline Number of employe & 0,565 & 3,60 & $0,000 *$ & 0,083 & 3,23 & $0,001 *$ & 0,083 & 3,23 & $0,001 *$ \\
\hline Driver's license ownership & 0,129 & 0,98 & 0,326 & 0,023 & 1,06 & 0,290 & 0,023 & 1,06 & 0,290 \\
\hline Vehicle ownership & $-0,239$ & $-0,88$ & 0,381 & $-0,467$ & $-1,01$ & 0,315 & $-0,467$ & $-1,01$ & 0,315 \\
\hline Number of room & 0,003 & 0,02 & 0,988 & 0,002 & 0,06 & 0,949 & 0,002 & 0,06 & 0,949 \\
\hline \multicolumn{10}{|l|}{ Occupation of the house head } \\
\hline officer & $-0,522$ & $-1,87$ & $0,061 *$ & $-0,077$ & $-1,54$ & 0,124 & $-0,077$ & $-1,54$ & 0,124 \\
\hline retired & $-0,225$ & $-0,82$ & 0,413 & $-0,054$ & $-1,11$ & 0,268 & $-0,054$ & $-1,11$ & 0,268 \\
\hline unemployed & 0,373 & 0,51 & 0,604 & 0,056 & 0,42 & 0,676 & 0,056 & 0,42 & 0,676 \\
\hline private sector employee & Reference & & & & & & & & \\
\hline \multicolumn{10}{|c|}{ Monthly income of the house } \\
\hline$<1.500 \mathrm{TL}$ & Reference & & & & & & & & \\
\hline $1.500-3.000 \mathrm{TL}$ & 0,364 & 1,49 & 0,136 & 0,069 & 1,56 & 0,118 & 0,069 & 1,56 & 0,118 \\
\hline$>3.000 \mathrm{TL}$ & 0,614 & 1,99 & $0,047 *$ & 0,101 & 1,86 & $0,063^{*}$ & 0,101 & 1,86 & $0,063 *$ \\
\hline \multicolumn{10}{|l|}{ Type of house } \\
\hline flat & $-0,135$ & $-0,21$ & 0,834 & $-0,012$ & $-0,11$ & 0,910 & $-0,128$ & $-0,97$ & 0,333 \\
\hline slum & 0,745 & 0,72 & 0,472 & 0,115 & 0,69 & 0,493 & $-0,115$ & $-0,69$ & 0,493 \\
\hline detached house & Reference & & & & & & & & \\
\hline \multicolumn{10}{|l|}{ House ownership } \\
\hline host & $-0,708$ & $-1,43$ & 0,154 & $-0,103$ & $-1,23$ & 0,219 & $-0,103$ & $-1,23$ & 0,219 \\
\hline tenant & $-0,899$ & $-1,80$ & $0,072 *$ & $-0,132$ & $-1,55$ & 0,121 & $-0,132$ & $-1,55$ & 0,121 \\
\hline other & Reference & & & & & & & & \\
\hline \multicolumn{10}{|l|}{ House size } \\
\hline$<100 \mathrm{~m}^{2}$ & Reference & & & & & & & & \\
\hline $100-200 \mathrm{~m}^{2}$ & 0,094 & 0,44 & 0,659 & 0,020 & 0,54 & 0,592 & 0,020 & 0,54 & 0,592 \\
\hline$>200 \mathrm{~m}^{2}$ & 0,484 & 0,45 & 0,656 & 0,072 & 0,39 & 0,697 & 0,072 & 0,39 & 0,697 \\
\hline \multicolumn{10}{|l|}{ Parking situation } \\
\hline roadside & 0,445 & 1,19 & 0,233 & 0,087 & 1,37 & 0,170 & 0,087 & 1,37 & 0,170 \\
\hline garage-parking area & 0,199 & 0,54 & 0,589 & 0,040 & 0,63 & 0,528 & 0,040 & 0,63 & 0,528 \\
\hline other & Reference & & & & & & & & \\
\hline Number of house & \multicolumn{2}{|c|}{600} & \multicolumn{4}{|c|}{600} & \multicolumn{3}{|c|}{600} \\
\hline Trip per person & \multicolumn{2}{|c|}{1,91} & \multicolumn{4}{|c|}{1,91} & \multicolumn{3}{|c|}{1,91} \\
\hline $\operatorname{LL}(\beta)$ & \multicolumn{2}{|c|}{$-1333,862$} & \multicolumn{4}{|c|}{$-1330,415$} & \multicolumn{3}{|c|}{$-1330,415$} \\
\hline LL(c) & \multicolumn{2}{|c|}{$-1451,225$} & \multicolumn{4}{|c|}{$-1442,877$} & \multicolumn{3}{|c|}{$-1438,655$} \\
\hline $\mathrm{R}^{2}$ & \multicolumn{2}{|c|}{0,081} & \multicolumn{4}{|c|}{0,078} & & 0,075 & \\
\hline AIC & 4,5 & & & 4 & & & & 4,51 & \\
\hline
\end{tabular}

*0.1 significant level of importance

\section{Results}

Stata 11.2 statistical software was used for regression analyses and Matlab 14.b software was used for ANN. It was checked whether there is a multiple linear connection between the variables for each province. It was observed that there is no multiple linear connection between independent variables, because the variance inflation values are less than $10 \%$ (table 2).

The results of regression analyses done on data sets for each province are presented in tables 3-5. The results obtained by using 3 different regression methods as
Multiple Linear Regression (MLR), Poisson Regression (PR), and Negative Binomial Regression (NBR) are given in the tables generated for each province.

Mc Fadden $\mathrm{R}^{2}$ values, which were calculated mutually by Stata software and the formulation of which is given below, were compared in MLR, PR, and NBR models.

$$
\text { McFadden } \mathrm{R}^{2}=1-[\operatorname{lnL}(\text { Mfull }) / \operatorname{lnL}(\text { Mintercept })]
$$

$\mathrm{L}=$ estimated likelihood, Mfull = model with predictors, Mintercept $=$ model without predictors. 
Table 4. Regression Analysis Results of Erzurum Province.

\begin{tabular}{|c|c|c|c|c|c|c|c|c|c|}
\hline \multirow{2}{*}{ Variables } & \multicolumn{3}{|c|}{ Multiple Linear Regression } & \multicolumn{3}{|c|}{ Poisson Regression } & \multicolumn{3}{|c|}{ Negative Binomial Regression } \\
\hline & Coefficient & t-Statistic & $\mathrm{P}>\mathrm{z}$ & Coefficient & t-Statistic & $\mathrm{P}>\mathrm{Z}$ & Coefficient & t-Statistic & $\mathrm{P}>\mathrm{Z}$ \\
\hline Constant & 1,957 & 2,68 & 0,008 & 1,159 & 6,37 & 0,000 & 1,159 & 6,37 & 0,000 \\
\hline Number of person & 0,713 & 7,63 & $0,000 *$ & 0,107 & 4,80 & $0,000^{*}$ & 0,107 & 4,80 & $0,000^{*}$ \\
\hline Number of student & 0,802 & 8,15 & $0,000 *$ & 0,111 & 4,78 & $0,000 *$ & 0,111 & 4,78 & $0,000^{*}$ \\
\hline Number of children & $-0,024$ & $-0,13$ & 0,894 & $-0,011$ & $-0,25$ & 0,799 & $-0,011$ & $-0,25$ & 0,799 \\
\hline Number of employe & 0,428 & 2,72 & $0,007 *$ & 0,060 & 1,62 & 0,105 & 0,060 & 1,62 & 0,105 \\
\hline Driver's license ownership & 0,052 & 0,52 & 0,602 & 0,019 & 0,81 & 0,415 & 0,019 & 0,81 & 0,415 \\
\hline Vehicle ownership & $-0,035$ & $-0,21$ & 0,832 & $-0,009$ & $-0,23$ & 0,816 & $-0,009$ & $-0,23$ & 0,816 \\
\hline Number of room & $-0,191$ & $-1,28$ & 0,202 & $-0,022$ & $-0,58$ & 0,562 & $-0,022$ & $-0,58$ & 0,562 \\
\hline \multicolumn{10}{|c|}{ Occupation of the house head } \\
\hline officer & $-0,078$ & $-0,34$ & 0,735 & $-0,003$ & $-0,05$ & 0,960 & $-0,003$ & $-0,05$ & 0,960 \\
\hline retired & $-0,027$ & $-0,10$ & 0,919 & $-0,024$ & $-0,37$ & 0,714 & $-0,024$ & $-0,37$ & 0,714 \\
\hline unemployed & 0,435 & 1,34 & 0,183 & 0,052 & 0,68 & 0,496 & 0,052 & 0,68 & 0,496 \\
\hline private sector employee & Reference & & & & & & & & \\
\hline \multicolumn{10}{|c|}{ Monthly income of the house } \\
\hline$<1.500 \mathrm{TL}$ & Reference & & & & & & & & \\
\hline $1.500-3.000 \mathrm{TL}$ & $-0,010$ & $-0,05$ & 0,960 & 0,003 & 0,05 & 0,958 & 0,003 & 0,05 & 0,958 \\
\hline$>3.000 \mathrm{TL}$ & 0,136 & 0,46 & 0,646 & 0,009 & 0,12 & 0,901 & 0,009 & 0,12 & 0,901 \\
\hline \multicolumn{10}{|l|}{ Type of house } \\
\hline flat & 0,376 & 1,30 & 0,196 & 0,042 & 0,60 & 0,550 & 0,042 & 0,60 & 0,550 \\
\hline slum & 0,302 & 0,39 & 0,694 & 0,045 & 0,26 & 0,792 & 0,045 & 0,26 & 0,792 \\
\hline detached house & Reference & & & & & & & & \\
\hline \multicolumn{10}{|l|}{ House ownership } \\
\hline host & 0,080 & 0,23 & 0,816 & 0,015 & 0,17 & 0,862 & 0,015 & 0,17 & 0,862 \\
\hline tenant & 0,216 & 0,61 & 0,543 & 0,028 & 0,33 & 0,743 & 0,028 & 0,33 & 0,743 \\
\hline other & Reference & & & & & & & & \\
\hline \multicolumn{10}{|l|}{ House size } \\
\hline$<100 \mathrm{~m}^{2}$ & Reference & & & & & & & & \\
\hline $100-200 \mathrm{~m}^{2}$ & $-0,209$ & $-0,82$ & 0,414 & $-0,038$ & $-0,60$ & 0,549 & $-0,038$ & $-0,60$ & 0,549 \\
\hline$>200 \mathrm{~m}^{2}$ & $-0,865$ & $-1,54$ & 0,124 & $-0,144$ & $-1,03$ & 0,303 & $-0,144$ & $-1,03$ & 0,303 \\
\hline \multicolumn{10}{|l|}{ Parking situation } \\
\hline roadside & 0,003 & 0,001 & 0,990 & 0,003 & 0,04 & 0,964 & 0,003 & 0,04 & 0,964 \\
\hline garage-parkingarea & 0,167 & 0,59 & 0,554 & 0,021 & 0,31 & 0,756 & 0,021 & 0,31 & 0,756 \\
\hline other & Reference & & & & & & & & \\
\hline Number of house & \multicolumn{2}{|c|}{400} & \multicolumn{4}{|c|}{400} & \multicolumn{3}{|c|}{400} \\
\hline Trip per person & \multicolumn{2}{|c|}{1,51} & \multicolumn{4}{|c|}{1,51} & \multicolumn{3}{|c|}{1,51} \\
\hline $\operatorname{LL}(\beta)$ & \multicolumn{2}{|c|}{$-740,098$} & \multicolumn{4}{|c|}{$-816,084$} & \multicolumn{3}{|c|}{$-816,084$} \\
\hline LL(c) & \multicolumn{2}{|c|}{$-923,055$} & \multicolumn{4}{|c|}{$-918,790$} & \multicolumn{3}{|c|}{$-918,790$} \\
\hline $\mathrm{R}^{2}$ & \multicolumn{2}{|c|}{0,198} & \multicolumn{4}{|c|}{0,112} & & 0,112 & \\
\hline AIC & 3,8 & & & 4 , & & & & 4,19 & \\
\hline
\end{tabular}

*0.1 significant level of importance.

Values very close to each other were obtained as the results of the PR and NBR analyses that were applied to the data set generated for the three provinces. Because the variance and average values were equal to each other and not very different from each other and because there was neither an equal distribution nor an extreme distribution in the data set, NBR and PR analysis results were approximately equal.

The compatibility of the model was compared with the data with multiple explanation multiplier $\mathrm{R}^{2}$ and Akaike information criterion AIC, the goodness of fit criteria for model performance evaluation. The highest $R^{2}$ was obtained in MLR model and the lowest AIC value was obtained in PR model for Ankara. The highest $\mathrm{R}^{2}$ and the lowest AIC values were obtained in MLR model in Erzurum and Bayburt. MLR has shown a better performance in all the three example provinces that were selected among the developed, developing, and non-developed provinces. The number of working people, the number of people, and the number of students are statistically the most significant independent variables among the household characteristics.

According to the results of the MLR model which gives the best results from the three regression models for Ankara, Erzurum and Bayburt provinces having different 
Table 5. Regression Analysis Results of Bayburt Province.

\begin{tabular}{|c|c|c|c|c|c|c|c|c|c|}
\hline \multirow{2}{*}{ Variables } & \multicolumn{3}{|c|}{ Multiple Linear Regression } & \multicolumn{3}{|c|}{ Poisson Regression } & \multicolumn{3}{|c|}{ Negative Binomial Regression } \\
\hline & Coefficient & t-Statistic & $\mathrm{P}>\mathrm{z}$ & Coefficient & t-Statistic & $\mathrm{P}>\mathrm{Z}$ & Coefficient & t-Statistic & $\mathrm{P}>\mathrm{Z}$ \\
\hline Constant & 2,277 & 3,45 & 0,001 & 1,170 & 7,47 & 0,000 & 1,170 & 7,47 & 0,000 \\
\hline Number of person & 0,648 & 6,72 & $0,000 *$ & 0,110 & 4,99 & 0,000 & 0,110 & 4,99 & $0,000^{*}$ \\
\hline Number of student & 0,990 & 9,07 & $0,000 *$ & 0,148 & 6,14 & 0,000 & 0,148 & 6,14 & $0,000^{*}$ \\
\hline Number of children & $-0,134$ & $-0,70$ & 0,485 & $-0,021$ & $-0,46$ & 0,645 & $-0,021$ & $-0,46$ & 0,645 \\
\hline Number of employe & $-0,582$ & 4,41 & $0,000 *$ & 0,041 & 1,52 & 0,127 & 0,041 & 1,52 & 0,127 \\
\hline Driver's license ownership & 0,249 & 2,40 & $0,017 *$ & 0,052 & 2,28 & $0,023^{*}$ & 0,052 & 2,28 & $0,023^{*}$ \\
\hline Vehicle ownership & 0,441 & 1,86 & $0,063^{*}$ & 0,093 & 1,76 & $0,078^{*}$ & 0,093 & 1,76 & $0,078^{*}$ \\
\hline Number of room & $-0,427$ & $-2,64$ & $0,009 *$ & $-0,060$ & $-1,58$ & 0,115 & $-0,060$ & $-1,58$ & 0,115 \\
\hline \multicolumn{10}{|c|}{ Occupation of the house head } \\
\hline officer & 0,403 & 1,49 & 0,137 & 0,088 & 1,37 & 0,170 & 0,088 & 1,37 & 0,170 \\
\hline retired & 0,382 & 1,42 & 0,155 & 0,018 & 0,28 & 0,781 & 0,018 & 0,28 & 0,781 \\
\hline unemployed & 0,036 & 0,07 & 0,946 & $-0,067$ & $-0,47$ & 0,641 & $-0,067$ & $-0,47$ & 0,641 \\
\hline private sector employee & Reference & & & & & & & & \\
\hline \multicolumn{10}{|c|}{ Monthly income of the house } \\
\hline$<1.500 \mathrm{TL}$ & Reference & & & & & & & & \\
\hline $1.500-3.000 \mathrm{TL}$ & $-0,435$ & $-2,08$ & $0,038 *$ & $-0,044$ & $-0,86$ & 0,389 & $-0,044$ & $-0,86$ & 0,389 \\
\hline$>3.000 \mathrm{TL}$ & $-0,123$ & $-0,40$ & 0,689 & $-0,009$ & $-0,12$ & 0,901 & $-0,009$ & $-0,12$ & 0,901 \\
\hline \multicolumn{10}{|l|}{ Type of house } \\
\hline flat & 0,364 & 1,93 & 0,054 & 0,049 & 1,09 & 0,277 & 0,049 & 1,09 & 0,277 \\
\hline slum & $-0,230$ & $-0,34$ & 0,735 & $-0,110$ & $-0,67$ & 0,500 & $-0,110$ & $-0,67$ & 0,500 \\
\hline detached house & Reference & & & & & & & & \\
\hline \multicolumn{10}{|l|}{ House ownership } \\
\hline host & 0,287 & 0,79 & 0,428 & $-0,000$ & $-0,00$ & 0,999 & $-0,000$ & $-0,00$ & 0,999 \\
\hline tenant & 0,384 & 1,000 & 0,319 & 0,031 & 0,35 & 0,730 & 0,031 & 0,35 & 0,730 \\
\hline other & Reference & & & & & & & & \\
\hline \multicolumn{10}{|l|}{ House size } \\
\hline$<100 \mathrm{~m}^{2}$ & Reference & & & & & & & & \\
\hline $100-200 \mathrm{~m}^{2}$ & $-0,022$ & $-0,09$ & 0,925 & $-0,023$ & $-0,40$ & 0,688 & $-0,023$ & $-0,40$ & 0,688 \\
\hline$>200 \mathrm{~m}^{2}$ & 1,412 & 2,12 & $0,035^{*}$ & 0,170 & 1,18 & 0,238 & 0,170 & 1,18 & 0,238 \\
\hline \multicolumn{10}{|l|}{ Parking situation } \\
\hline roadside & 0,149 & 0,50 & 0,620 & 0,029 & 0,42 & 0,677 & 0,029 & 0,42 & 0,677 \\
\hline garage-parkingarea & $-0,173$ & $-0,54$ & 0,591 & $-0,031$ & $-0,42$ & 0,675 & $-0,031$ & $-0,42$ & 0,675 \\
\hline other & Reference & & & & & & & & \\
\hline Number of house & \multicolumn{2}{|c|}{385} & \multicolumn{4}{|c|}{385} & \multicolumn{3}{|c|}{385} \\
\hline Trip per person & \multicolumn{2}{|c|}{1,48} & \multicolumn{4}{|c|}{1,48} & \multicolumn{3}{|c|}{1,48} \\
\hline $\operatorname{LL}(\beta)$ & \multicolumn{2}{|c|}{$-736,913$} & \multicolumn{4}{|c|}{$-789,534$} & \multicolumn{3}{|c|}{$-789,534$} \\
\hline LL(c) & \multicolumn{2}{|c|}{$-948,619$} & \multicolumn{4}{|c|}{$-951,778$} & \multicolumn{3}{|c|}{$-942,532$} \\
\hline $\mathrm{R}^{2}$ & \multicolumn{2}{|c|}{0,223} & \multicolumn{4}{|c|}{0,170} & & 0,162 & \\
\hline AIC & 3,5 & & & 4 & & & & 4,22 & \\
\hline
\end{tabular}

*0.1 significant level of importance.

development levels, the independent variables of the number of individuals and the number of students are statistically significant in all three provinces, and the trip generation is increased. In other words, whether the level of development of the provinces increases or decreases, as the number of people and the number of students in the household increase so will the number of total trips that the household produce. While in Ankara and Erzurum provinces the variable "the number of employees in the household" increases the trip generation, in Bayburt this variable decreases the trip generation. This is because as the development level of the provinces increases, the after work social activities of the people working in these provinces also increase, and this increases trip generation. The fact that Bayburt is an nondeveloped province, and that there are not many attractions decreases the trips that the working people produce. In Ankara province, the officer category of the categorical variable of the household head occupation was statistically significant while the other two did not. The trips that the officers generate by visiting the attraction centers after work can be suggested as a reason for that. This is the natural result of the increase in the rate of province's development level and joining social activities. 


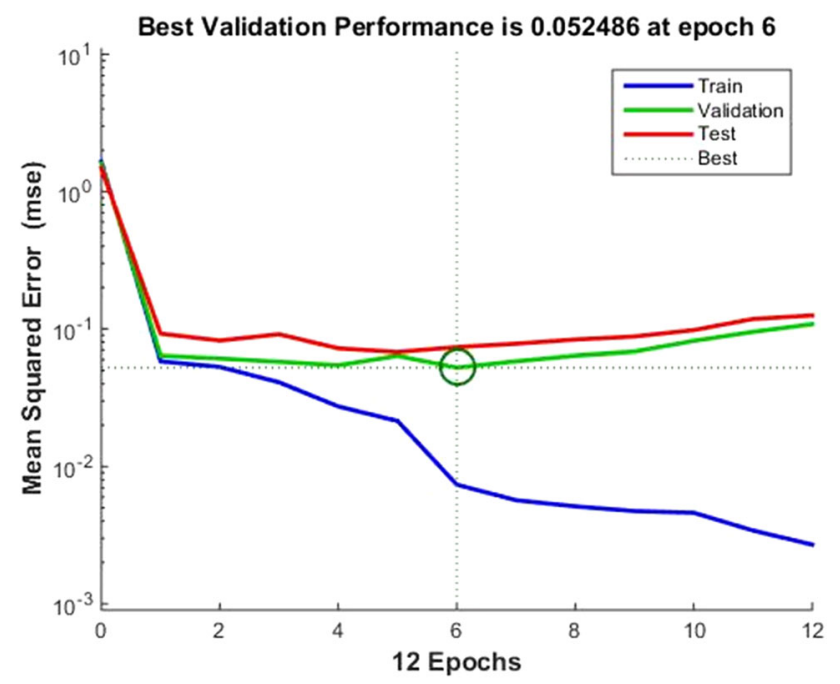

Figure 2. MSE change for training, validation and test data sets in training process of Ankara ANN model.

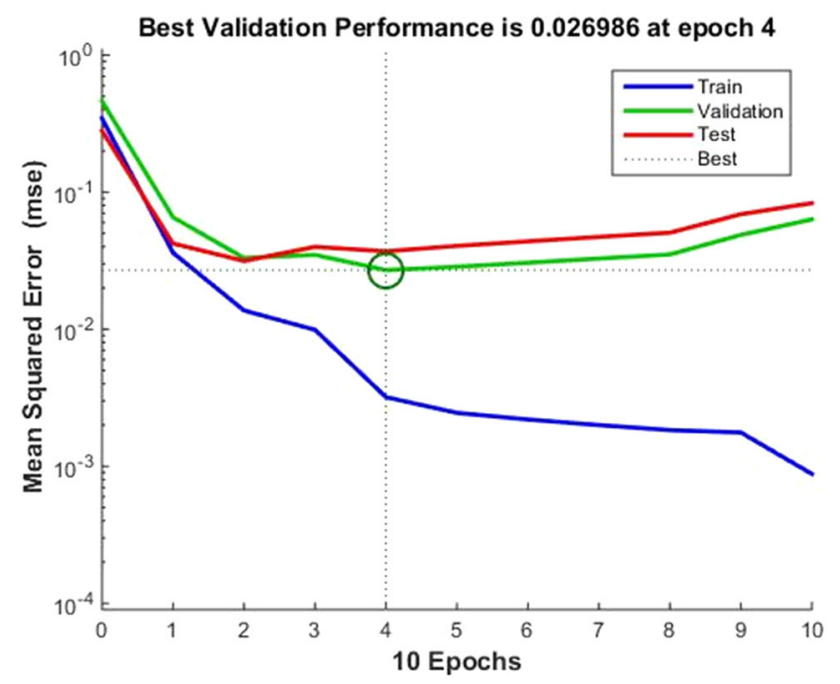

Figure 3. MSE change for training, validation and test data sets in training process of Erzurum ANN model.

In the province of Ankara, in the categorical variable of "monthly income of the household" the trips that the highincome-households generate are more than the trips that the low-income-households generate. While in Ankara high income variable $(>3000)$ is statistically significant, in Erzurum and Bayburt provinces it is not the case. The developed province of Ankara has more attraction centers than Erzurum and Bayburt. As a result, with the increase of the the monthly income of the household in Ankara, the trips they generate also increase.

"House ownership" categorical variable in Ankara province was statistically significant, but Erzurum and Bayburt did not show significance in this category.

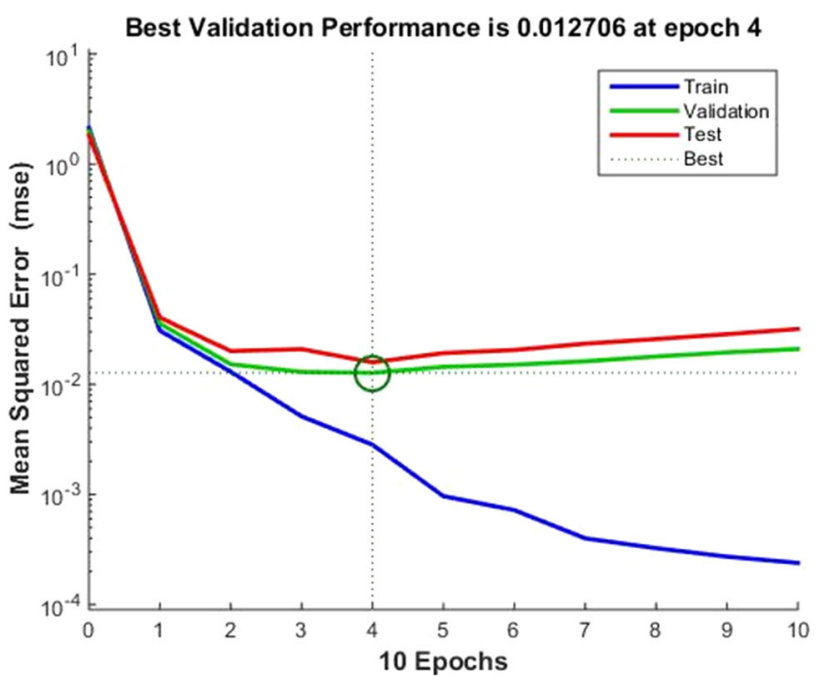

Figure 4. MSE change for training, validation and test data sets in training process of Bayburt ANN model.

Table 6. Results of ANN Model.

\begin{tabular}{lcccccc}
\hline Province & $\mathrm{R}^{2}$ & MAPE & MAE & MSE & RMSE & AIC \\
\hline Ankara & 0,8982 & 4,8887 & 0,0873 & 0,0128 & 0,1131 & 1,06 \\
Erzurum & 0,9457 & 2,1352 & 0,0519 & 0,0049 & 0,0701 & 1,70 \\
Bayburt & 0,9578 & 1,6642 & 0,0399 & 0,0028 & 0,0531 & 1,16 \\
\hline
\end{tabular}

Table 7. Comparison of MLR and ANN Models.

\begin{tabular}{lccccccc}
\hline \multirow{2}{*}{$\begin{array}{l}\text { Model } \\
\text { Province }\end{array}$} & \multicolumn{3}{c}{ MLR } & & & \multicolumn{3}{c}{ ANN } \\
\cline { 2 - 3 } \cline { 6 - 7 } \cline { 7 - 8 } & $\mathrm{R}^{2}$ & RMSE & AIC & & $\mathrm{R}^{2}$ & RMSE & AIC \\
\hline Ankara & 0,32 & 2,27 & 4,52 & & 0,89 & 0,11 & 1,06 \\
Erzurum & 0,59 & 1,58 & 3,81 & & 0,94 & 0,07 & 1,70 \\
Bayburt & 0,67 & 1,68 & 3,94 & & 0,95 & 0,05 & 1,16 \\
\hline
\end{tabular}

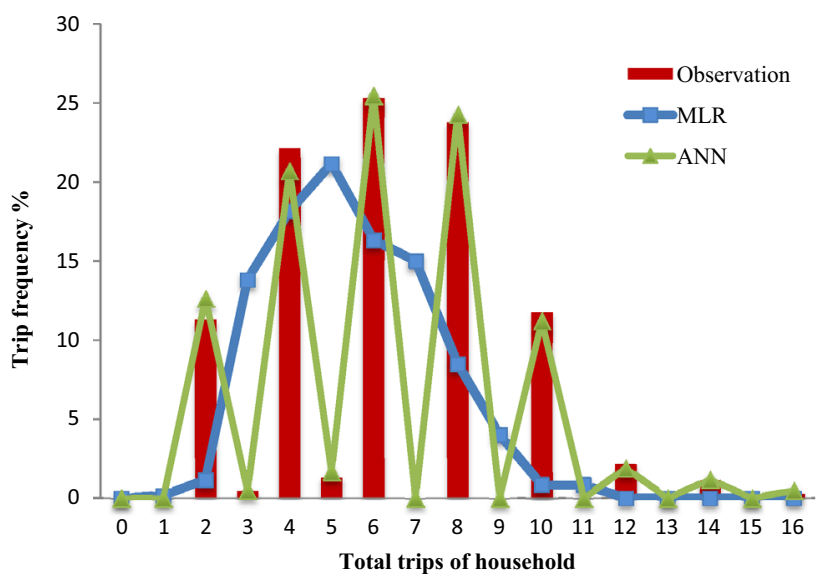

Figure 5. Observation and prediction trips for Ankara province. 


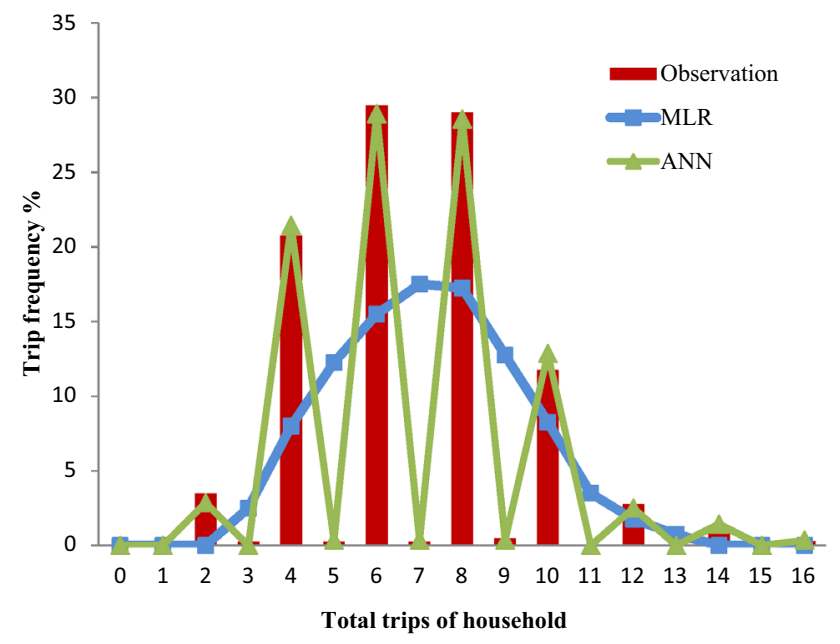

Figure 6. Observation and prediction trips for Erzurum province.

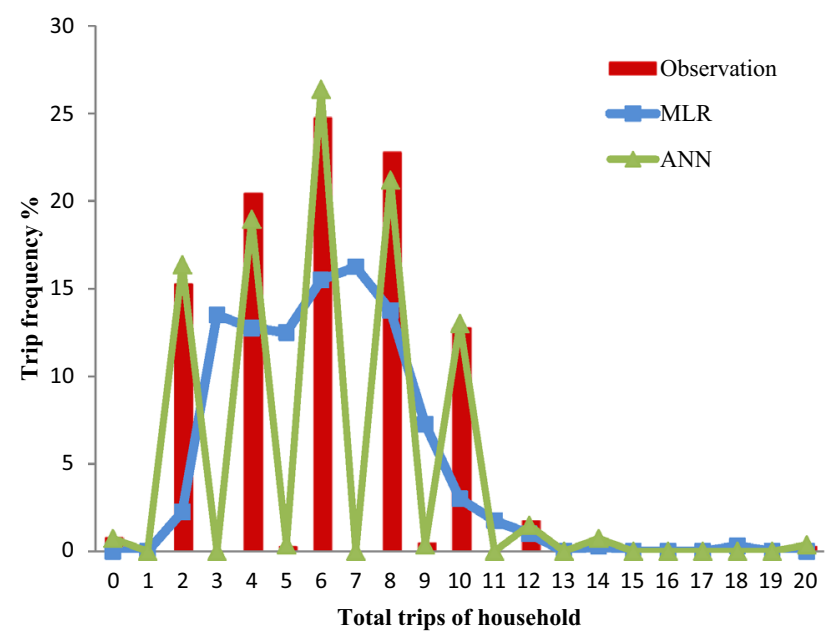

Figure 7. Observation and prediction trips for Bayburt province.

Whereas having a driving license was not statistically significant in trip generation in Ankara and Erzurum, it came out to be significant in Bayburt. In the province of Bayburt, houses with more driver's license and vehicle ownership increase the trip generation. In Ankara and Erzurum provinces, these two variables were not statistically significant. In other words, vehicle ownership has no significant effect on trip generation for Ankara and Erzurum provinces. As the level of development of the provinces increases, the population and the ownership of the vehicles also increase, so the use of public transportation is preferred. Therefore, in the developed province of Ankara and the developing province of Erzurum, vehicle and driver's license ownership may not be significant for the trip generation. Because, whether they have a car and driver's license or not, people can increase trip generation with different forms of public transport. However, Bayburt, which is not a developed province, does not have many alternative systems of public transport. Therefore, in Bayburt, people are increasing their trip generation by using their private cars or on pedestrian (as it is a small province).

In the nondeveloped province of Bayburt, as the number of rooms in the household increases, the trip generation decreases. This is because of the lack of social activity centers, and as people's habitat expands, they spend their times with different activities in their houses. In addition, households in Bayburt having a moderate monthly income affect the trip generation negatively.

In relevant graphs (best validation performance graphs for the 3 provinces) are expected to show low MSE values. MSE is expected to show the same tendency in the test and validation curves while having a decreasing tendency in the training curve. In the 6th epoch of the model created for the province of Ankara and in the 4th epoch for Erzurum and Bayburt provinces, the MSE values were found to increase in contrast to the training curve of validation curve and it stopped learning to take measures against overfitting (figures 2-4).

The validation and test curves are very similar. If the test curve had increased significantly before the validation curve increased, then it is possible that some overfitting might have occurred. But the ANN Model for Ankara, Erzurum and Bayburt does not involve overfitting (figures 2-4).

When Ankara, Erzurum and Bayburt provinces are compared, according to the ANN model results, the model results for ANN for Bayburt province, which is not developed, are better than the other two. That is to say, the Bayburt province ANN model has high $\mathrm{R}^{2}$ value and low error rates (table 6).

At the end, the AIC values and $\mathrm{R}^{2}$ values of the three regression models for the three provinces were compared and MLR model was determined as the best model for the three data sets. Later, MLR model and ANN model were compared according to $\mathrm{R}^{2}$, RMSE and AIC criterions. The results of ANN model came out to be better than MLR model for higher $\mathrm{R}^{2}$ and lower error values were obtained in ANN model (table 7).

Six comparison criteria such as Mean Squared Error (MSE), Root Mean Square Error (RMSE), $\mathrm{R}^{2}$ (Explanation Multiplier), Mean Absolute Error (MAE), Mean Absolute Percentage Error (MAPE) and Akaike information criteria (AIC) were used in the study. The mathematical formulations belonging to these are given below:

$$
\begin{aligned}
& \text { RMSE }=\sqrt{\frac{1}{N} * M S E} \\
& \mathrm{MSE}=\sum_{i=1}^{N}\left(t_{i}-g_{i}\right) / \mathrm{N}
\end{aligned}
$$




$$
\begin{array}{r}
\mathrm{R}^{2}=1-\left[\sum_{i=1}^{N}\left(y_{i}-\hat{y}_{i}\right)^{2} / \sum_{i=1}^{N}\left(y_{i}-\bar{y}_{i}\right)^{2}\right] \\
\mathrm{MAE}=\frac{1}{n} \sum_{i=1}^{n}\left|e_{i}\right| \\
\mathrm{MAPE}=100 *\left|\sum_{i=1}^{N}\left(t_{i}-g_{i}\right)^{2} / \mathrm{t}_{\mathrm{i}}\right| / \mathrm{N} \\
\mathrm{AIC}=\log (\mathrm{MSE})+2 *(\mathrm{~m}+1) / \mathrm{N}_{\mathrm{a}}
\end{array}
$$

$\mathrm{N}=$ number of observations, $t_{i}$ the real value of the $\mathrm{i}^{\text {th }}$ unit, $g_{i}$ the predicted value of the $\mathrm{i}^{\text {th }}$ unit, $e_{i}$ prediction error, $y_{i}$ the real value of the dependent variable, $\hat{y}_{i}$ predicted value of the dependent variable $\bar{y}_{i}$ the mean of the dependent variable, $\mathrm{N}_{\mathrm{a}}$ is number of trained data and $\mathrm{m}$ is the number of parametrs in the model (it is the total number of weights and invariables in the net structure).

According to Lewis, models whose MAPE (\%) value is under $10 \%$ are "very good", between $10 \%$ and $20 \%$ are "good", models between $20 \%$ and $50 \%$ are "acceptable", and models above 50\% are classified as "wrong and false". Because the MAPE values obtained in ANN model are below $10 \%$, we can classify it as a "very good model" [24].

When table 7 is examined, the performance of ANN model have given better results with high $\mathrm{R}^{2}$ and low error values according to MLR model in the analysis results obtained in three provinces, whose development levels are different. When the provinces are compared, $\mathrm{R}^{2}$ decreases and RMSE increases as the development index increases.

In figure 5, the frequencies of trips are presented in response to the trip produced by each house, which is obtained as a result of the survey study done for Ankara. There is an important difference between the prediction values and observation values of MLR model. In ANN model, prediction values closer to the reality are obtained. Similar results were obtained in Erzurum and Bayburt (figures 6 and 7). ANN model was selected as the model with the best performance in the modeling of trip generation for the provinces with three different development levels.

\section{Discussion and conclusions}

In most of the studies in the literature, due to the superior features of the ANN, the ANN model gave better results than the regression models. But there are studies that ANN does not outperform. For example, Tillema et al (2004), assessed the performance of the ANN model and regression model in their study. However, the performance of the two models was also good and not significantly different from each other (RMSE was used as a comparison criteron). This study has shown that ANN is not superior to classical regression models in cases where data are few. In our study, ANN model outperformed regression models both by estimating trip generation and in terms of model comparison criteria within the three provinces. In another study, to estimate trip generation, regression methods and ANN were applied to data set created by questionnaire surveys conducted in 60 sites in Delaware [25]. In this study, ANN model outperformed regression models. Goel and Sinha (2008), modeled trip generation using ANN model in their study. They designated Meerut City as a study area and the disturbance terms of the model performance evaluation criteria were quite low [26]. As for our study, trip generation models of three provinces in different development levels were compared instead of one province, in addition, the $\mathrm{R}^{2}$, RMSE, and AIC values of the model performance evaluation criteria were compared and the best prediction model was selected for the trip generation. This model is used for prediction but, identifying the structural relationships and testing statistical significance are not performed in this study. These functions can be applied in the future research.

Trip generation is the first step in the traditional fourstage transportation planning model, in which the obtained data used for trip distribution, modal split and assignment of traffic. Therefore, to identify the trip generation is very important because it forms the basis of the other three stages. Obtaining the trip generation data by accurate and reliable methods increases the reliability of estimation results. Furthermore, it is easier to construct regression models than ANN model. Because there is no general rule for network architecture in the model of ANN. The trial and error method is the only way to obtain optimum network architecture. This requires more time to build the ANN model.

Poisson and negative binomial regression methods, which are count data models applied to the data sets that include non-negative data, were used as an alternative for the traditional linear regression method used for trip generation. Although count data models have superior properties in literature, they have not given significant results in the data set that we have used in this study. In this study, multiple linear regression model is the model that has shown the best performance among the models applied to the data obtained with the survey study done in the provinces with three different development levels in Turkey. Multiple Linear regression model and Artificial Neural Networks model were compared. To sum up, ANN model was selected as the best model for trip generation compared to multiple linear regression model and count data model for three different provinces in this study. But, that does not mean that is the best possible linear model that could have been tested. While the development levels of the provinces increase, trip generation per person also increases, but the significance of the variables in the generated models 
decreases. When the values of Bayburt, as an example of non-developed provinces, that are obtained as a result of the analyses are examined, it can be seen that the variables are statistically more significant.

\section{Acknowledgement}

This study was supported by the Scientific Research Projects of Ataturk University under project number 2014-189.

\section{List of Symbols}

$\begin{array}{ll}\alpha & \text { distribution parameter } \\ \beta & \text { beta coefficient } \\ \mu & \text { population mean } \\ \mathrm{d} & \text { deviation } \\ e & \text { prediction error } \\ \varepsilon & \text { error term } \\ \mathrm{E} & \text { expected value } \\ g & \text { predicted value } \\ \mathrm{i} & \text { number of houses, } \\ \mathrm{L} & \text { estimated likelihood } \\ \mathrm{m} & \text { number of parameters }\end{array}$

$\mathrm{m}^{2} \quad$ square meter

n number of sample

$\mathrm{n}$ number of independent variables,

$\mathrm{N}$ number of observations

$\mathrm{N}_{\mathrm{a}}$ number of trained data

$\mathrm{p}$ incidence of the events to be examined

$\mathrm{q}$ not the incidence of the events to be examined

$\mathrm{R}^{2} \quad$ R-squared

$t$ real value

$\mathrm{V}$ variance

$\mathrm{X}$ independent variables

$\bar{y}$ mean of the dependent variable

$y_{i} \quad$ real value of the dependent variable,

$\hat{y}_{i}$ predicted value of the dependent variable

$\mathrm{Y}$ dependent variable

$\mathrm{Z}$ theoreticial values

Table 8. Development groups in Turkey according to development index of the province (DIP)[27].

\begin{tabular}{|c|c|c|c|c|c|c|c|c|c|c|c|}
\hline act & Province & DIP & act & Province & DIP & act & Province & DIP & act & Province & DIP \\
\hline 1 & İstanbul & 36,56 & 22 & Hatay & 0,37 & 43 & Karaman & $-1,08$ & 64 & Kilis & $-1,97$ \\
\hline 2 & Ankara & 12,54 & 23 & Isparta & 0,23 & 44 & Rize & $-1,10$ & 65 & Çankırı & $-1,98$ \\
\hline 3 & İzmir & 8,84 & 24 & Çanakkale & 0,13 & 45 & Sivas & $-1,12$ & 66 & Van & $-2,16$ \\
\hline 4 & Antalya & 6,85 & 25 & Yalova & $-0,05$ & 46 & Burdur & $-1,18$ & 67 & Gümüşhane & $-2,19$ \\
\hline 5 & Bursa & 4,14 & 26 & Bolu & $-0,09$ & 47 & Şanlıurfa & $-1,29$ & 68 & Adiyaman & $-2,22$ \\
\hline 6 & Kocaeli & 3,40 & 27 & Edirne & $-0,24$ & 48 & Bartın & $-1,43$ & 69 & Yozgat & $-2,28$ \\
\hline 7 & Muğla & 2,64 & 28 & 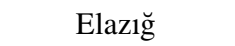 & $-0,51$ & 49 & Kırşehir & $-1,44$ & 70 & Bayburt & $-2,34$ \\
\hline 8 & Adana & 2,09 & 29 & Kütahya & $-0,54$ & 50 & Amasya & $-1,47$ & 71 & Kars & $-2,39$ \\
\hline 9 & Konya & 2,07 & 30 & Zonguldak & $-0,56$ & 51 & Tokat & $-1,47$ & 72 & Tunceli & $-2,47$ \\
\hline 10 & Gaziantep & 1,79 & 31 & Kırklareli & $-0,64$ & 52 & Çorum & $-1,48$ & 73 & Şırnak & $-2,54$ \\
\hline 11 & Eskişehir & 1,74 & 32 & Malatya & $-0,77$ & 53 & Ordu & $-1,55$ & 74 & Bingöl & $-2,67$ \\
\hline 12 & Denizli & 1,28 & 33 & Nevşehir & $-0,89$ & 54 & Aksaray & $-1,56$ & 75 & Siirt & $-2,72$ \\
\hline 13 & Mersin & 1,26 & 34 & Afyon & $-0,90$ & 55 & Erzincan & $-1,57$ & 76 & Iğdır & $-2,91$ \\
\hline 14 & Kayseri & 1,17 & 35 & Erzurum & $-0,91$ & 56 & Artvin & $-1,62$ & 77 & Muş & $-2,98$ \\
\hline 15 & Trabzon & 0,76 & 36 & Kahramanmaraş & $-0,96$ & 57 & Osmaniye & $-1,63$ & 78 & Bitlis & $-3,02$ \\
\hline 16 & Tekirdağ & 0,65 & 37 & Düzce & $-0,96$ & 58 & Kastamonu & $-1,64$ & 79 & A ğr1 & $-3,02$ \\
\hline 17 & Sakarya & 0,52 & 38 & Karabük & $-0,97$ & 59 & Giresun & $-1,71$ & 80 & Ardahan & $-3,04$ \\
\hline 18 & Balıkesir & 0,49 & 39 & Uşak & $-0,98$ & 60 & Niğde & $-1,73$ & 81 & Hakkari & $-3,15$ \\
\hline 19 & Samsun & 0,43 & 40 & Kırıkkale & $-1,01$ & 61 & Batman & $-1,80$ & & & \\
\hline 20 & Manisa & 0,39 & 41 & Diyarbakır & $-1,05$ & 62 & Sinop & $-1,84$ & & & \\
\hline 21 & Aydın & 0,37 & 42 & Bilecik & $-1,06$ & 63 & Mardin & $-1,86$ & & & \\
\hline
\end{tabular}




\section{References}

[1] Lord D, Washington S P and Ivan J N 2005 Poisson, poissongamma and zero-inflated regression models of motor vehicle crashes: Balancing statistical fit and theory. Accid. Anal. Prev 37: 35-46

[2] Goulias K G 1990 Praticial method for the estimation of trip generation and trip chaining. Transp. Res. Rec. 1991: 47-56

[3] Rengaraju V R and Satyakumar M 1994 Structuring category analysis using statistical technique. J. Transp. Eng. 120: 930-939

[4] Rengaraju V R and Satyakumar M 1995 Three-dimensional category analysis using probabilistic approach. J. Transp. Eng. 121: 538-543

[5] Anderson M D and Malave D N 2003 Dynamic trip generation for a medium-sized urban community. Transp. Res. Rec.: J. Transp. Res. Board 1858: 118-123

[6] Tillema F, Zuilekom K, Maarseveen M and Huisken G 2004 Trip generation and trip distribution: comparison of neural networks and traditional methods. In: 10th World Conference on Transportation Research, WCTR 2004, Istanbul, Turkey, July 4-8

[7] Badoe D and Chen C 2004 Modeling trip generation with data from single and two independent cross-sectional travel surveys. J. Urban Plan. Dev. 130: 167-174

[8] Jang T Y 2005 Count data models for trip generation. J. Transp. Eng. 131: 444-450

[9] Gamas J A, Anderson W P and Pastor C 2006 Estimation of trip generation in Mexico City, Mexico, with spatial effects and urban densities. Transp. Res. Rec.: J. Transp. Res. Board 1985: 49-60

[10] Kwigizile V and Teng H 2009 Comparison of methods for defining geographical connectivity for variables of trip generation models. J. Transp. Eng. 135: 454-466

[11] Oyedepo O and Makinde O 2009 Regression model of household trip generation of Ado-Ekiti township in Nigeria. Eur. J. Sci. Res. 28: 132-140

[12] Lim K K and Srinivasan S 2011 Comparative analysis of alternate econometric structures for trip generation models. J. Transp. Res. Board 2254: 68-78
[13] Daniel E and Ituen U 2013 Inter-urban trip generation models for the urban centers in Akwa Ibom State, Nigeria. Civ. Environ. Res. 3: 55-62

[14] Huntsinger L F, Rouphail N M and Bloomfield P 2013 Trip generation models using cumulative logistic regression. $J$. Urban Plan. Dev. 139: 176-184

[15] Chang J S, Jung D, Kim J and Kang T 2014 Comparative analysis of trip generation models: results using home-based work trips in the Seoul metropolitan area. Transp. Lett. 6: 78-88

[16] Özçelik D A 1981 Research techniques regulation and analysis. Ankara: ÜSYM Publising, pp. 74

[17] TSI (Turkish Statisticial Institute), 2004 Address based population registration system results. http://tuikapp.tuik. gov.tr/adnksdagitapp/adnks

[18] Kutner M H, Nachtsheim C J, Neter J and Li W 2005 Applied linear statistical models. 5th edition, New York: McGrawHill Irwin Companies inc, pp. 26-27

[19] Cameron A C and Trivedi P K 2013 Regression analysis of count data. New York: Cambridge University Press, pp. 9-10

[20] Hilbe J M 2011 Negative binomial regression. New York: Cambridge University Press, pp. 187-190

[21] Haykin S 1999 Neural networks: a comprehensive foundation. 2nd edition, Pearson Education, Mc Master University Press, Canada, pp. 23-24

[22] Barnard E 1992 Optimization for training neural nets. IEEE Trans. Neural Netw. 3: 232-240

[23] Öztemel E 2011 Artificial neural networks. İstanbul: Papatya Press, pp. 48-51

[24] Lewis C D 1982 Industrial and business forecasting methods. London: Butterworths, pp. 40-41

[25] Faghri A and Aneja S 1996 Artificial neural network-based approach to modeling trip production. Transp. Res. Rec.: J. Transp. Res. Board 1556: 131-136

[26] Goel S and Sinha A K 2008 Trip generation modeling using artificial neural network. In: Proceedings of the 2nd National Conference India Computing For Nation Development, India, pp. 495-498

[27] Eraydın K, Gül E, Çevik B and Demir E 2012 Research development levels of province in Turkey, Turkey İs Bank, Economic Research Department, İstanbul 